\title{
清酒の健康と美容効果（光の 3）
}

\section{今安 聰・川戸章嗣}

\section{はじめに}

本稿では日本酒の美容に関する話題を取り上げるが, 前稿で述べた適量飲酒で健康を保持することが最高の 美容につながることはいうまでもない。

昨年末, NHK から日本酒の美容効果について取材, 撮影の依頼があった。その内容は「日本酒には民間伝

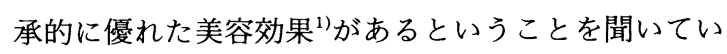
る。酒風呂, 酒粕風呂は昔から美容だけでなく, 薬用 にも効果があるといわれているが, 月桂冠研究陣によ

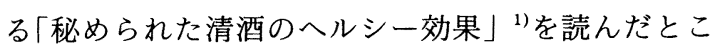
ろ, 日本酒の美容効果について研究され, 実証されて いるのを知った。実際に行われた研究について取材, 撮影したいがいかがですか。」との依頼であった。実 際に取材を始めると, 日本酒には驚くほどの美容効果 があり, その検証のために各地に飛んで取材を行って いるとのことで，これからまだ数力所廻って，その美 容効果についての話を伺いにいくとのことであった。 その後, NHK で放映され, 日本酒の美容効果につい て科学的なデー夕をふまえて紹介されていた。

日本酒の薬用効果については本稿「清酒の健康と美 容効果」と「(その 2)」で適量飲酒による効用とその 効用を示す物質がどのようなものであるかということ について詳細に説明したが，それ以外にもたくさんの 効用がある。例えば，元中日ドラゴンズの谷沢選手の 有名な経験談がある。それは断裂したアキレス腱に日 本酒を湿布薬として患部に塗り, マッサージすること によって傷が完治し，見事にその翌年「首位打者」を 獲得したという話である ${ }^{2)}$ 。また, 日本相撲協会診療 所医師の林博士は大相撲の力士に対し, 他の酒類と比 較して保温性の高い日本酒を大いに奨めていることな
ど，そのメカニズムは不明でも，日本酒を評価した民 間伝承的な事実がたくさんある。これらは日本酒中に 含まれる何百という成分が肌へのすぐれた湿潤作用を もたらしていることを証明するものである。

本稿では私共が行った日本酒の美容効果の研究のみ

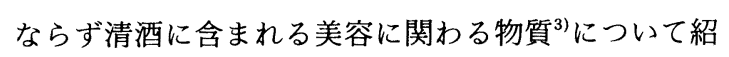
介し, 日本酒の優れた美容効果を検証する。

\section{1）保温・保湿効果}

つやつやした肌, みずみずしい肌を保つ要因は脂質 と水であり, どちらも適量存在することが重要である。 しかし, 一般には脂質や水分は多くの人は不足がちで あり, 特に加齢に従い不足する傾向が強くなり, 徐々 に潤いのないカサカサした肌になる。みずみずしい肌 を保つためには, 皮膚の皮質膜や角質層の状態を見な がら適度な脂質と水分を補給することが重要である。 脂質の補給の場合は乳液などを表皮に塗ることによ り簡単に補給することができるが, 水分の補給は単に 水を塗るだけではすぐに蒸発し効果が得られない。そ こで保湿成分と呼ばれる皮膚から水分を蒸発しにくく する物質が必要になる。皮膚の水分は皮脂膜の下にあ る角質層に蓄えられているため, 保湿成分とは皮脂膜 を通して水分を角質層に溶かしこむ働きを持つ物質で ある。現在化粧品として利用されている保湿成分とし ては，グリセロールやアミノ酸などの生体代謝物や七 アルロン酸やコラーゲンのような皮膚を構成する成分 などがある。日本酒にはグリセロールやアミノ酸など 他の酒類に比べ多くの保湿成分が含まれている。それ ゆえ, 日本では「酒風呂」でその効果を見いだし, 昔 から美容と健康のために利用されてきたわけである。

「酒風呂」に入ると血行を促して体を暖めるなどの 保温効果 (温浴効果, 温度維持効果) や肌がしっとり

Effectiveness of Sake on Your Health \& Beauty Satosi Imayasu, Akistugu Kawato (Gekkeikan Sake Co., Ltd) 
し，つやが増してすべすべになる美容効果があるとい われている。私共はこの効果を確認するため, 実際に 入浴して酒風呂の保温効果や保湿効果について調べ た

お湯 $200 \ell$ に対し, 日本酒 $1 \ell$ （当社上撰）を入れ， 湯温を $42^{\circ} \mathrm{C}$ に設定して, 5 分間入浴した (パネラー 10 人)。入浴後経時的に表面温度計で皮膚の温度を, IBS 社製皮表角層水分量測定装置 (SKIN SURFACE HYGROMETER) で皮膚に微量の高周波を 流すことにより，その伝導度を応用して皮膚角質層の 水分量を測定した。その結果を示したのが第 1 図と 2 図である。酒風呂につかることにより $0.5 \sim 1^{\circ} \mathrm{C}$ 高く 温度が保持され, 保温効果のあることが確認され，ま た保湿効果についても図に示すように, 有意に保湿性 が高いことがわかる。NHK の取材の中でも, 特に興 味を抱かれたのは保温性に関してである。化粧品開発 の研究の中で保湿性というのは重要なテーマであるが, 保温性ということについては具体的に取り上げた研究 は珍しく, それ故, 当社の研究に注目したということ
である。

現在, その効果をもたらす物質が何か検討中である が, 日本酒には他の酒類と違い米を原料として, しか も酵母や䴯という 2 種類の微生物を用いるため, 多く の発酵産物, 例えばアミノ酸, 有機酸, 糖類, 無機成 分, ビタミン, 核酸, エステル等何百種類という物質 が日本酒中で生産されてくる。それらが絡み合って, その機能を増幅していると考えることができる。

\section{2） 美白効果 ${ }^{5)}$}

人間の皮膚の色をきめるのは, 主にメラニンという 色素の量である。メラニンは本来紫外線などから体を 守る役目を持つ物質であるが，これが大量に沈着する とシミ, ソバカス, 老人性ホクロになる。メラニンは つぎのような生成路で生成される。

メラニンを生成する経路の中で最も重要な物質は, 上記に示すチロシナーゼという酵素である。この酵素 を働かせないようにすることにより，メラニンの生成 量を減少させ, 美白作用の保持やシミ, ソバカスを防 ぐことができる。このチロシナーゼの働きを抑える物

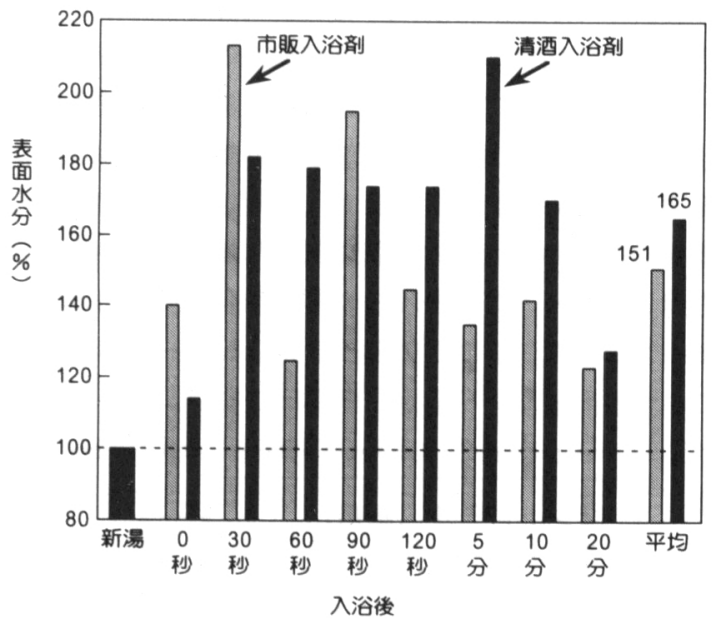

第 1 図 清酒の保湿効果

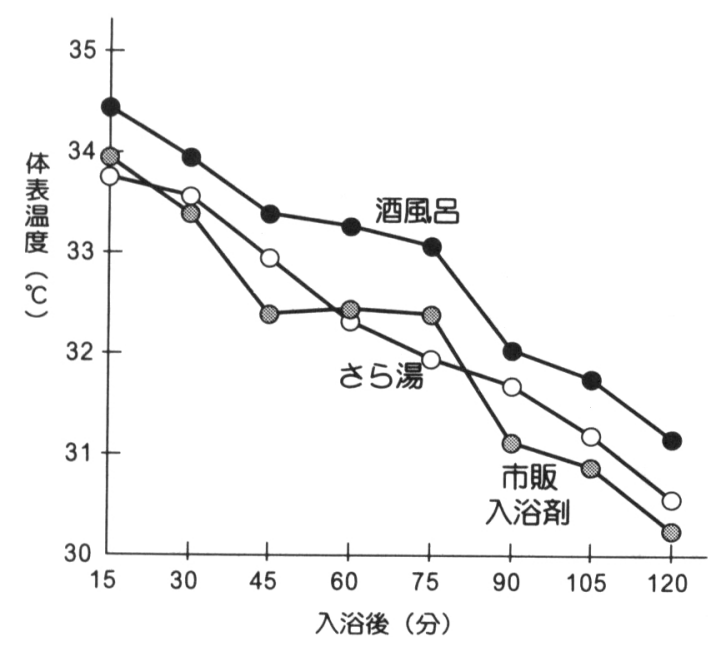

第 2 図 酒風呂の保温効果

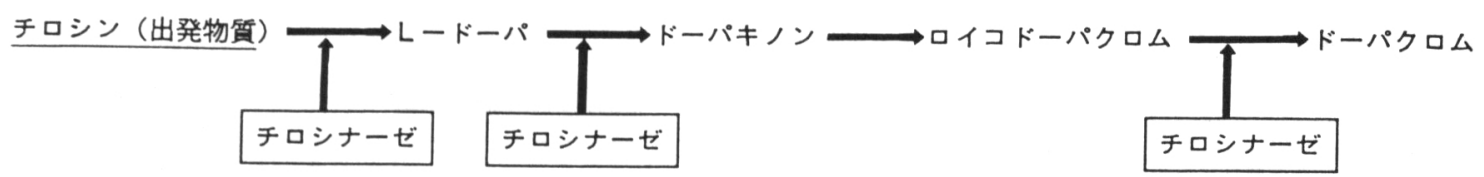

5，6ジヒドロキシインドル —インドールー5，6ーキノン メラニン

第 3 図メラニンの合成経路 
質が多数見つけられているが, 中でもコケモモやナシ に含まれるアルブチンにメラニン生成を抑制する効果 が認められている。このアルブチンを配合した化粧品 が, 美白効果をもつ商品として現在市販されている。

日本酒, 酒粕, 䴯の中にもアルブチンと同様にチシ ロナーゼの働きを抑える作用を持つ物質が多数含まれ ている。ビタミン Eがその効果を持つ。中でも䴯中 に多く含まれる遊離リノール酸は, 実際に細胞のメラ ニン合成量を低下させる効果が証明されている（第 4 $(\text { 図 })^{6)}$ 。このことより, 昔から酒や麴を扱う杜氏の手 が白くてつるつるとしてきれいといわれてきたことが この美白成分の存在により科学的に説明されることに なり，その効果が明らかになったのである。

\section{3）あれ肌を予防する}

日本酒は昔から化粧水としても使われていたことが 知られている7)。現在化粧料として用いられている 様々な糖質やアミノ酸が日本酒に多く含まれているこ とから, 当然古くからそのような使われ方をされてき たことが理解できる。しかし, その肌への効用が何に よるものかは解明されていなかった。堀越等 ${ }^{81}$ は日本 酒の肌に対する作用機作とその有効成分を明らかにす る目的で研究を行った。研究はマウスUVあれ肌モ デル (ヘアレスマウスにUV 照射し, あれ肌を誘発 させたマウス）を用い, 日本酒濃縮液を照射前に 1 日 1 回, 5 日連続で塗布し, 照射直後から照射後 3 日目 まで塗布した。誘発したあれ肌の判定は経皮水分蒸散 量 (Trans-Epidermal Water Loss TEWL)を測

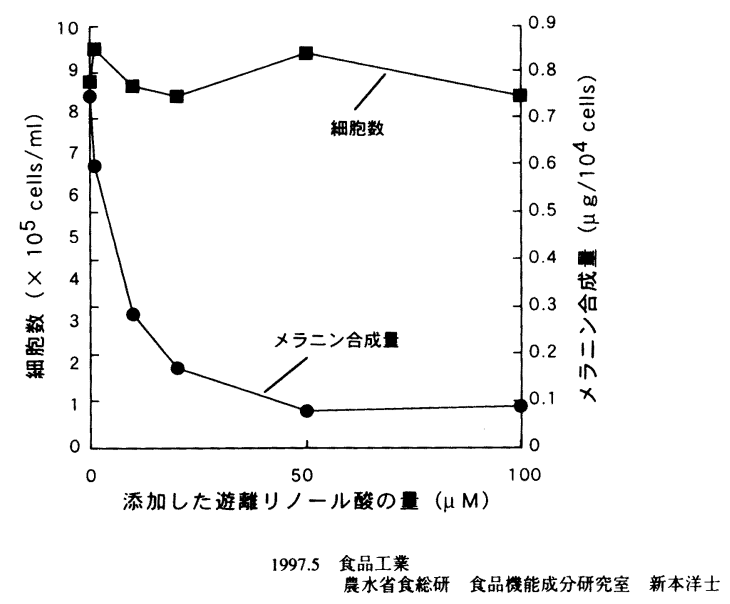

第 4 図遊離リノール酸の添加によるメラニン合 成量と細胞数の変化
定することによって行った。

その結果を示したのが図 5 である。日本酒濃縮物を 塗布した群は有意に TEWL に顕著な上昇抑制があり, あれ肌を抑制する効果のあることが確認された。

また, 日本酒の濃縮物中のあれ肌抑制物質は清酒中 では苦み成分として知られる $\alpha$-エチルグルコシド $(\alpha-$ EG）であった。この $\alpha$-EG の作用は表皮細胞の角化 （表皮細胞の分化の過程を角化と呼ぶ-一表皮は基底 細胞, 有棘細胞, 顆粒細胞と順次形態的に特徵のある 細胞に変化しながら表層へと移動し, 最終的に角質細 胞になる。表皮のもっとも重要な生理機能は紫外線な どの物理的, 化学的刺激に対する防御壁となる角質層 を形成すること。）を促進させる作用があることが判 明した。

以上のように科学的に証明されることにより, 日本 酒が昔から化粧水やまた酒風呂として使われてきた理 由の一つであることが明らかとなった。

\section{4）アトピー性皮夙炎を予防する}

アトピー性皮膚炎はアレルギー疾患の一つである。 アトピーとはギリシャ語の ATOPOS（奇妙な）から きた言葉で “奇妙な病気”といった意味もあるが，ア トピー性皮膚炎のように, 皮膚組織の特徵をさして使 われる。また, アレルギーとはギリシャ語の ALLOS (変わった）と ERGON（作用, 働き）がくつついた 言葉で“変わった反応”といった意味を持っており, 皮膚のみならず全身の症状に対して使う。しかし，現 在はアトピーとアレルギーは同義語として扱われてい る。

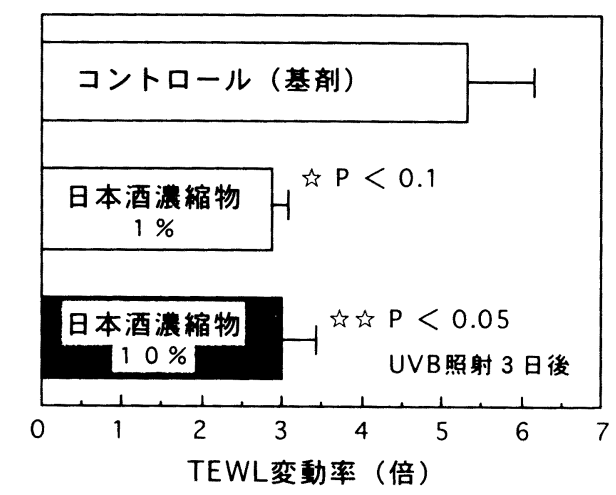

第 5 図UVB照射マウスに対する日本酒濃 縮物のあれ肌阻害効果 (TEWL 增 加） 
アトピー性皮膚炎は, 皮膚を保護する皮脂や角質層 に問題があり, 健康人と比べ污れやすく, ウイルス等 に対する抵抗力の低下やいろいろな刺激に対して敏感 になっていることにより現れてくる症状である。すな わち, 花粉, 食べ物やダニなどに対し, 過剩に反応す ることにより直ちにその症状がでてくるアレルギー反 応である。このようにすぐに反応ができる即時型のア レルギーをアトピーと呼ぶ。

アトピー性皮膚炎を改善するため患部に米発酵エキ ス9（米に米䴯とアミラーゼを加えて反応させ酵母を 添加後発酵させ, 濾過したもので日本酒に近いと考え られる）を塗布すると保湿性が向上することによりア レルギー皮膚炎が改善されたという報告がある。これ は前述の保温・保湿性のところで述べたように日本酒 そのものの保湿性がアトピー性皮膚炎を治癒させる効 果につながっており，塗布することにより体の外から 治療する効果が日本酒にあると考えられる。また，一 方体の中から，すなわち日本酒を飲むことによりアレ ルギーを防止する方法がある。私共はそれを見いだし たのである。

このことを紹介するには花粉, 食べ物やダニアレル ギーがどのようなものか, またどのような発症機序に より生じるか説明する必要がある。

アレルギーと身体を守るために働く免疫の機能とは, 表裏一体の関係にある。すなわち, 免疫機能が時には 障害反応となって病気の原因となり, 過敏症あるいは アレルギーを引き起こすのである ${ }^{10)}$ 。

アレルギーには, 抗原と接触して発症するまでの時 間によって, 前述の即時型過敏症と遅延型過敏症の二 つに分類される。即時型の代表的な反応として，花粉， 食物やダニアレルギー，じんましんなどが生じる I 型, 血液型不適合による溶血反応を示すII型, 血清病など を引き起こすIII型, そして遅延型の代表的な反応であ るツベルクリン反応などの四つに分類される。

我が国における即時型食物アレルギーの実態につい て厚生省によって平成 9 年度に 2 万人を対象として調 査された。現在, 百人に一人の割合で患者がいると報 告され，ひどい場合には死にいたることもあるといわ れている。また, この即時型アレルギーは食物, 花粉, ダニ等に含まれる蛋白質によって引き起こされること が知られており, その発症のメカニズムは次の通りで ある。すなわち，第 6 図に示すように抗原が体内に入
ると, マクロファージ等の貧食細胞に取り込まれて分 解される。抗原の種類を示すためにその一部が表面に 開示され, 体の免疫機構はこの時始めて異物を攻撃の 対象として認識する。

異物の攻撃する白血球の一つであるへルパーTリ ンパ球は開示された抗原に接触し, 認識するとマクロ ファージを活性化させ, 異物を食い殺させる Th 1 リ ンパ球とアレルギーを起こす免疫グロブリン E ( IgE $)$ 等の抗体生産を命じるTh 2 リンパ球に分化する。続 いてインターロイキン-4（IL-4）により B 細胞を活 性化し, IgE 抗体が産生される。

$\mathrm{IgE}$ 抗体は血流に入って全身の肥満細胞や好塩基球 とレセプターを介して感作が成立する。この感作状態 で再び同じ抗原と接触すると, 抗原と IgE抗体が結 合しレセプターと架橋し，これが契機となって肥満細 胞が活性化され，ヒスタミン，セロトニンなどケミカ ルメディエーターが放出される。これら化学伝達物質 の平滑筋収縮作用や血管透過性亢進作用によってアレ ルギー症状が発現するわけである。

ヘルパーTリンパ球は活性化される際, マクロフ アージが持つシステインプロテアーゼである「カテプ シン B」という酵素によって二種類のリンパ球に分化 することが知られている。このカテプシン Bがアレ ルギーを起こすことになっていることがマウスを用い た徳島大学医学部のグループの実験 ${ }^{11} に よ り$ 明らかに された。すなわち，カテプシン B の阻害剤をマウス に投与することにより, 免疫グロブリンが産生せず, アレルギーが発症しないことを明らかにした。

この酵素を特異的に阻害する物質であるエポキシコ 八ク酸の誘導体が日本酒やその原料である麳に含まれ ていることを私共は発見し，現在 5 種類の阻害剤を同 定した ${ }^{12)}$ 。第 1 表に示すように, 各種システインプロ テアーゼに対するこれら 5 種類の酵素阻害物質はアレ ルギーを予防すると考えられるカテプシン B やその 他パパインなどのシステインプロテアーゼを強く阻害 し，また市販のシステインプロテアーゼ阻害剤である E-64よりいずれも強く, 特に CPI-3 は 10 倍以上の 阻害活性を持つ阻害剤であることが明らかとなった。

以上, 日本酒の適量飲酒により花粉, 食べ物, ダニ アレルギーに対して予防効果があることが示唆される。 体の内側, 外側から日本酒を用いることにより, アト ピー性皮膚炎など, 皮膚のかゆみ, 瞼や唇の腫れ, 蹃 


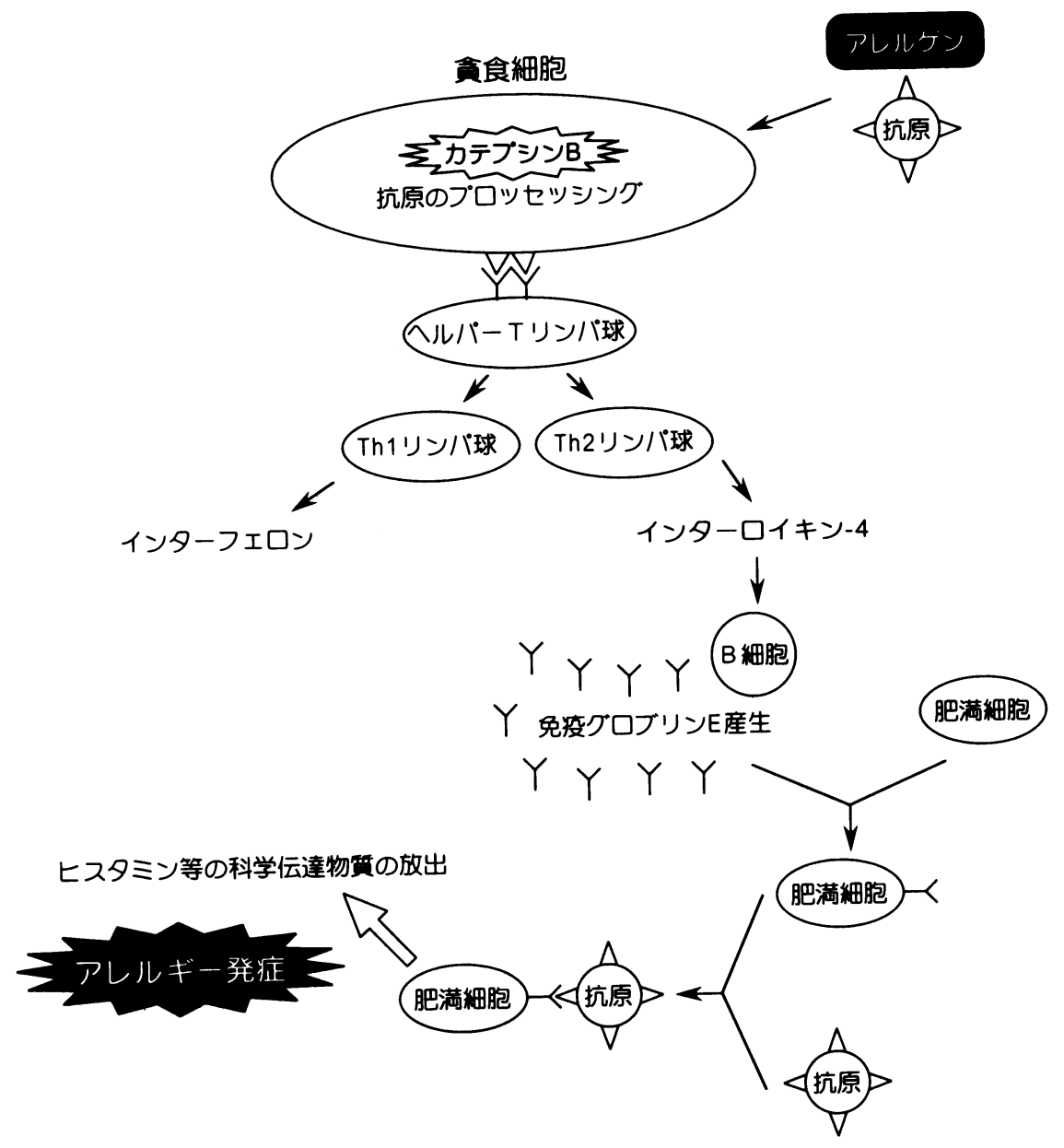

第 6 図 アレルギー発症のメカニズム

第 1 表 システインプロテアーゼ（カテプシン B）に対する阻害活性

\begin{tabular}{|c|c|c|c|c|c|c|c|}
\hline & \multirow{2}{*}{$\begin{array}{c}\text { 酥素量 } \\
(\mathrm{ng} / \mathrm{ml})\end{array}$} & \multicolumn{5}{|c|}{$1 C_{50} \quad(\mathrm{ng} / \mathrm{ml})$} & \multirow[b]{2}{*}{$E-64$} \\
\hline & & $\mathrm{CPI}-1$ & CPI-2 & CPI-3 & $\mathrm{CPI}-4$ & $\mathrm{CPI}-5$ & \\
\hline カテプシンB & 1.88 & 9.432 & 1.431 & 0.780 & 1.802 & 10.310 & 10.678 \\
\hline パパイン & 2.0 & 0.890 & 8.453 & 3.740 & 8.169 & 2.576 & 1.355 \\
\hline フィチン & 100 & 23.705 & 19.857 & 7.765 & 14.717 & 40.493 & 6.596 \\
\hline ブロメライン & 500 & 11.429 & 11.202 & 4.127 & 80.72 & 29.163 & 5.376 \\
\hline
\end{tabular}

麻疹などの不快な症状から解放されることが期待され るわけである。

\section{5）老化防止}

日本酒中にはフェルラ酸という抗酸化物質が含まれ ており ${ }^{13)}$ ，老化防止作用が期待されている。フェルラ 酸の効用が明らかにされつつあり, 現在解明されてい る作用は主として次の 6 つである。
1. 抗酸化作用：油脂の酸化を押さえたり, 活性酸 素による遺伝子がダメージを受けるのを押さえる。

2. 紫外線吸収作用：太陽光線のうち人体に悪影響 を与える波長の光 $(320 \mathrm{~nm} \sim 400 \mathrm{~nm})$ を吸収し, 紫 外線による発ガンを抑制し, 化粧品の原料として有望 視されている。

3. 種子の発芽抑制作用：タマネギ, ニンニク, ジ 
ヤガイモなどの発芽抑制に期待がかかる。

4. 抗菌剤：黄色ブドウ球菌に対する薬剤が開発さ れている。

5．木材への薬注入を容易にできる：シロアリを除 いたり，防腐効果のある木材を開発。

6. 発ガンの予防薬：フェルラ酸を用いた発ガン予 防版を開発中。

フェルラ酸は米の細胞壁の構成成分であり, 強い抗 酸化作用並びに紫外線吸収作用を持っていることが証 明されている。皮膚の老化，しわに対しては光，すな わち紫外線が大きな影響を与えていることが科学的に 証明されている。例えば, 炎天下の下, 農作業を営む 人のしわは老人といわれる年齢でもないにもかかわら ずかなり多いことがよく見受けられる。これは常時紫 外線に当たっているためである。日本酒に含まれるフ エルラ酸の紫外線吸収作用は強く, 皮膚表面の老化を 抑えるといわれ，有望な化粧品候補となっている。ま た，日本酒を飲むことにより，その強い抗酸化作用の ため体の中で脂質の過酸化反応を抑制し, 生き生きと した若さを保つことが期待される。日本酒と上手につ きあっている人の顔は年齢より若く見える。

\section{6) 肥満防止}

若い女性にとって肥満は天敵である。肥満と美容は 相容れず，肥満を抑えるため若い女性がダイエットに 励むわけである。また人間にとって肥満は生活習慣病, 例えば糖尿病の原因ともなり, 合併症など併発して最 悪の結果を生むことにもなりかねないのでエネルギー の摂取には注意を払う必要がある。

一般にアルコール飲料はそれが持つアルコールのカ ロリーが高いため, 酒を飲むと太るという考えが持た れている。アルコール $1 \mathrm{~g}$ は $7.1 \mathrm{Kcal}$ のネルギー を産生することから, 高いアルコールを飲酒すれば, 自ずから高エネルギーを摂取することになる。しかし， Pirola と Lieber ${ }^{14), 15)}$ はアルコール摂取量を増加させ, その分のエネルギーを食事で減らして体重変化を調べ てみると, 体重が減少すると報告している。また食事 のエネルギー量を変化させず，アルコールによるエネ ルギーを途中から加えて, 体重の変化をみたところ体 重は増加はそれほど顕著ではないという結果が得られ た。この結果はアルコールは同じエネルギーの炭水化 物, 蛋白質や脂肪より体重増加作用が低いということ を示しており，実際にはアルコール $1 \mathrm{~g}$ は $7.11 \mathrm{Kcal}$
のエネルギーを産生しないと考えられている。さらに アルコールの代謝を考えた場合, ATP 合成を伴う系 とエネルギー物質が生産されない microsomal ethanol oxydizing system (MEOS) の系があり, また, TCA に入らずカルボリガーゼ経路をとると高エネル ギー物質は生産されない。このような高エネルギーを 産生しない経路をとれば, アルコールはエネルギー源 としての役割を果たさないといわれている。

飲酒する場合, 大事なことはそれぞれの栄養成分を バランス良く摂取することであり，そのうえでアルコ ールを楽しめばよいということである。

日本酒にはアルコール以外にもアミノ酸や糖など含 んでいるからカロリーが高く太りやすいという誤った 考えを持つ人がいる。愛媛大学の奥田教授は日本酒や 酒粕には澱粉の吸収を阻害し, 蛋白質の吸収を促進す る物質が含まれていることを確認しており,この作用 は肥満を防止する物質の存在を示唆するものだと報告 している ${ }^{16)}$

以上の研究結果から, 日本酒の適量飲酒と日本の伝 統的な食生活を守ることが健康で美容にも良く, 長寿 につながると結論できるのである。

\section{おわりに}

本稿では日本酒が美容に効果があるということを述 べた。そのほか, 日本酒の美容に関し数多くの伝承的 事実が存在する。例えば，ひびあがれれの手がつるつ るになる。火傷が早く治る。シミそばかすに対する美 白効果等である。今明らかになりつつある事実と重複 しているところもあるが, その美容効果が実証されつ つある。また, 前稿の「清酒の健康と美容効果」と $「(そ の 2) 」 て ゙$, 日本酒の適量飲酒が長寿と健康をも たらすということを述べたが，体が健康であれば肌の 色つやも良く美容にも良く, すなわち健康イコール美 容という図式も描けるわけである。以上のことから総 括すると, 日本酒は体の中からのみならず外からも健 康や美容に寄与しているといえる。

科学の発達していない時代から, 日本では薬の代わ りに日本酒が用いられてきた過去の歷史がある。その 薬効の事実が今明らかにされたとしても驚くには当た らないと思う人がいるかもしれないが，私共等はその 効果を詳細に科学的に研究することにより, 日本酒の 美味しさだけでなく体にも非常によいことを科学的な 
裏付けをもって明らかにした。この真実を積極的に伝 え, 未来永劫に日本酒を楽しんでいただきたいと願う わけである。

$<$ 月桂冠(株) $>$

\section{参 考 文 献}

1）今安 聰著：「秘められた清酒のヘルシー効果」 地球社, 東京, 1997

2）「灘の酒博物館」講談社, 東京, 1983

3）滝澤行雄, 監修：「酒粕のすごい特効」宙出版, 東京，1998

4）未投稿

5）藤本大三郎著：「スキンケアの科学」講談社, 東京, 1992

6）新本洋士：食品工業，40（9， 88～91（1997）

7) 石橋四郎著：「和漢酒文献類聚」酉文社, 東京 (1936)

8）堀越俊雄, 原武昭憲, 池本毅, 太田裕紀子, 丹 野修, 北村伸夫：J. Soc. Cosmet. Chem.
Japan 32 (1), 10 16 (1998)

9) 藤岡彰, 酒井知恵, 羽金重喜, 米元康蔵, 西山 茂夫：西日皮膚，56，1（1994）

10）小山次郎, 大沢利明著：免疫学の基礎（第 2 版）東京化学同人 (1993)

11) Y. Matsunaga, T. Saibara, H. Kido, and N. Katsunuma: FFBS. Lett., 324 325 330 (1993)

12) T. Yamada, J. Hiratake, M. Aikawa, T. Suizu, Y. Saito, A. Kawato, K. Suginami and J. Oda : Biosci. Biotech. mol Biochem., 62 (5) 907 914 (1998)

13）太田剛雄, 高下秀春, 䔯木康市, 岩野君夫, 大 場俊輝：醸協 87，（12）922～926（1992）

14）糸川嘉則, 栗山欣也, 安本教傳責任編集:「ア ルコールと栄養」光生館, 東京 (1992)

15) Pirola, R. C. and Lieber, C. S. : Pharmacology, 7, 185 (1972)

16）奥田拓道，近木麻里子：「『酒造副生産物（酒 粕）に関する研究』報告書」 1995 